\title{
Review \\ Stem cell transplantation for rheumatic autoimmune diseases
}

\author{
Thomas Hügle ${ }^{1}$ and Jacob M van Laar²
}

\begin{abstract}
1Department of Rheumatology, University of Basel, Felix Platter Spital, Burgfelderstrasse 101, 4012 Basel, Switzerland
${ }^{2}$ Musculoskeletal Research Group, Institute of Cellular Medicine, The Medical School, Framlington Place, Newcastle University, Newcastle upon Tyne, $\mathrm{NE} 24 \mathrm{HH}, \mathrm{UK}$
\end{abstract}

Corresponding author: Jacob M van Laar, j.m.van-laar@ncl.ac.uk

Published: 10 October 2008

This article is online at http://arthritis-research.com/content/10/5/217

(C) 2008 BioMed Central Ltd

Arthritis Research \& Therapy 2008, 10:217 (doi:10.1186/ar2486)

\begin{abstract}
Immunoablative therapy and hematopoietic stem cell transplantation (HSCT) is an intensive treatment modality aimed at 'resetting' the dysregulated immune system of a patient with immunoablative therapy and allow outgrowth of a nonautogressive immune system from reinfused hematopoietic stem cells, either from the patient (autologous HSCT) or a healthy donor (allogeneic HSCT). HSCT has been shown to induce profound alterations of the immune system affecting $B$ and $T$ cells, monocytes, and natural killer and dendritic cells, resulting in elimination of autoantibodyproducing plasma cells and in induction of regulatory T cells. Most of the available data have been collected through retrospective cohort analyses of autologous HSCT, case series, and translational studies in patients with refractory autoimmune diseases. Long-term and marked improvements of disease activity have been observed, notably in systemic sclerosis, systemic lupus erythematosus, and juvenile idiopathic arthritis, and treatment-related morbidity and mortality have improved due to better patient selection and modifications of transplant regimens. Treatment-related mortality has decreased to approximately $7 \%$. Prospective, randomised, controlled clinical trials are ongoing or planned in systemic sclerosis, systemic lupus erythematosus, and several nonrheumatological conditions.
\end{abstract}

\section{Introduction}

Data from nearly 1,000 patients with refractory autoimmune disease $(A D)$ treated with hematopoietic stem cell transplantation (HSCT) have been collected by the European Group for Blood and Marrow Transplantation/European League Against Rheumatism (EBMT/EULAR) Working Party for Autoimmune Diseases in the past 10 years (Tables 1 and 2; Riccardo Saccardi, chair of the EBMT/EULAR Working Party, personal communication) [1-4]. The advent of this multistep treatment modality (Figure 1) followed clinical observations of remissions of $A D$ in patients who were transplanted for concomitant hemato-oncological conditions [5]. The immunological principles were subsequently confirmed through mechanistic studies in animal models of $A D$ [6]. HSCT in AD was widely pioneered in the 1990s at a time when few biologicals were available to treat $A D$ and when refractory progressive disease posed a major challenge. The introduction of effective biologicals for the treatment of rheumatoid arthritis (RA), juvenile idiopathic arthritis (JIA), ankylosing spondylitis, and systemic lupus erythematosus (SLE) has reduced the demand for intensive and toxic treatments such as HSCT. Nevertheless, clinicians still face cases of severe and life-threatening $A D$ such as progressive systemic sclerosis (SSc), vasculitis, or SLE, refractory to conventional medication and biologicals, for whom HSCT may be a therapeutic option. Whereas biologics target one cell type or soluble cytokine only, HSCT affects all immune effector cells involved in AD, notably $B$ and $T$ lymphocytes, monocytes, natural killer (NK) cells, and dendritic cells (DCs). In contrast to conventional immunosuppressive medication and biologicals, HSCT offers the prospect of a long-term remission of $A D$, but its attendant risks preclude routine use.

Hematopoietic stem cells (HSCs) are progenitor cells of platelets, erythrocytes, granulocytes, B and T lymphocytes, monocytes, tissue macrophages, and DCs. Animal studies have demonstrated that HSCs play an important role in the pathogenesis of AD. Adoptive transfer of HSCs after immunoablative therapy caused, prevented, or cured $A D[7,8]$. It was therefore postulated that underlying defects predisposing for

$\mathrm{AD}=$ autoimmune disease $; \mathrm{ANA}=$ antinuclear antibody ASSIST = American Scleroderma Stem Cell versus Immune Suppression Trial; ASTIS = Autologous Stem Cell Transplantation International Scleroderma; ATG = antithymocyte globuline; BM = bone marrow; DC = dendritic cell; DMARD = disease-modifying antirheumatic drug; EAE = experimental autoimmune encephalomyelitis; EBMT/EULAR = European Group for Blood and Marrow Transplantation/European League Against Rheumatism; GVHD = graft-versus-host disease; HSC = hematopoietic stem cell; HSCT = hematopoietic stem cell transplantation; IL = interleukin; JIA = juvenile idiopathic arthritis; $M S=$ multiple sclerosis; NK = natural killer; PBSC = peripheral blood stem cell; RA = rheumatoid arthritis; SCOT = Scleroderma: Cyclophosphamide or Transplantation Trial; SLE $=$ systemic lupus erythematosus; SLEDAI = Systemic Lupus Erythematosus Disease Activity Index; SSc = systemic sclerosis; TBI = total body irradiation; TRM = treatmentrelated mortality. 
Table 1

\begin{tabular}{lcc}
$\begin{array}{l}\text { Hematopoietic stem cell transplantation in autoimmune } \\
\text { disease }\end{array}$ & 993 \\
\hline Patients & $36 / 64$ \\
Male/Female, percentage & $185 / 27$ \\
Centres/Countries & 1,015 & \\
Transplant procedures & Autografts & $\begin{array}{c}\text { Allografts } \\
n=65\end{array}$ \\
\hline \multicolumn{4}{c}{$\mathrm{n}=950$} & 47 \\
\hline First transplant & 941 & 14 \\
Second transplant & 9 & 4 \\
Third transplant & & 14 (0.4 to 57) \\
Age at transplant, years & $36(2.7$ to 76$)$ & \\
\hline
\end{tabular}

Pooled data from the EBMT/EULAR (European Group for Blood and Marrow Transplantation/European League Against Rheumatism) Registry, August 2008.

AD may reside in the HSCs and that HSCT could be an effective treatment of AD. The aim of allogeneic HSCT is to replace host autoaggressive immune effector cells with donor-derived nonautoaggressive cells as a means of inducing tolerance and sustained remission of AD. Allogeneic HSCT, however, can result in graft-versus-host disease (GVHD), a potentially severe and life-threatening complication, thus making it less attractive as a treatment for AD. The observation that transplantation of syngeneic (genetically identical) HSCs works in experimental models of AD raised the prospect that autologous HSCT might be an equally effective treatment for human AD. Recent translational studies have shown that immunoablative therapy and autologous HSCT result in not only suppression and/or eradication of autoaggressive lymphocytes but also induction of regulatory $\mathrm{T}$ cells, thus 'resetting' the immunological clock (Figure 2). Both autologous and allogeneic HSCTs are used in conjunction with immunoablative conditioning, typically with high doses of cyclophosphamide, combined with antithymocyte globuline (ATG) and/or total body irradiation (TBI). The use of classical myeloablative regimens with busulfan and TBI is less attractive in AD because of the high treatmentrelated mortality (TRM). The reinfusion of autologous HSCs after conditioning serves mainly to shorten aplasia and reduce the risk of bleeding and infection, although there is evidence that the transplanted graft can have an immunomodulatory effect on its own [9]. Important lessons have been learned from clinical and translational studies in patients treated with HSCT, which will be discussed in this review.

\section{Preclinical data}

Transplant studies in animals with $A D$ are divided in genetically determined and inducible models. Mice or rats with lupus-like syndrome, transgenic HLA-B27 expression, nonobese diabetes, and interleukin-1 receptor antagonist
(IL-1Ra) deficiency belong to the first category, whereas those with collagen-induced arthritis or experimental autoimmune encephalomyelitis (EAE) as models of RA and multiple sclerosis (MS), respectively, belong to the second category. Different results were obtained in these models [6]. Conditioning followed by syngeneic (that is, pseudoautologous) HSCT resulted in the cure of induced $A D$, but not of genetically determined AD [10-12]. In autologous HSCT, and to a lesser extent in allogeneic HSCT, the outcome depended on the stage of the disease at the time of transplant $[13,14]$. In inducible disease models, protective as well as therapeutic effects of HSCT were observed: both syngeneic and allogeneic HSCTs in EAE-susceptible mice protected animals from disease when performed close to immunisation, but only allogeneic HSCT with high-grade chimerism was effective in protection against EAE when the time lag was longer. In another EAE study, HSCT prevented glial scarring and ameliorated disease severity after immunisation but was ineffective as a treatment of established disease [13,14]. In established genetic AD such as in lupus-prone mice, allogeneic, but not syngeneic, HSCT reversed both acute and chronic symptoms [12].

In the early animal HSCT studies, myeloablative conditioning was employed prior to allogeneic HSCT to achieve full donor chimerism and eradicate autoreactive lymphocytes. More recent studies, however, have shown that nonmyeloablative conditioning is equally effective in inducing stable chimerism, while maintaining efficacy $[12,15]$. Of note, no GVHD was observed, indicating that the putative graft-versusautoimmunity effect and GVHD are dissociated. Whereas full donor chimerism was needed in the SLE and EAE models, the induction of mixed chimerism was sufficient to ameliorate chronic inflammatory arthritis in IL-1Ra-deficient mice $[11,12,16]$. In the latter, no significant relationship between the arthritis score and the ratio of donor to recipient cell populations in mice with mixed chimerism could be found after allogeneic HSCT.

Other strategies to induce donor chimerism have been pursued as well. Costimulatory blockade without cytoreductive treatment proved sufficient to induce mixed chimerism in another murine model [17]. HSCs home to specialised niches [18]. If occupied by host stem cells that escaped the conditioning, a donor HSC cannot enter these niches. Administration of ACK2, an antibody that blocks c-kit function in HSCs, led to a transient depletion of greater than $98 \%$ of endogenous HSCs in immunodeficient mice. C-kit is a protooncogene encoding a tyrosine kinase that (together with its ligand) is important for the maintenance of hemopoietic progenitor cells [19]. Subsequent transplantation of these mice with donor HSCs and without conditioning led to chimerism levels of up to $90 \%$.

In collagen-induced arthritis, nonmyeloablative conditioning followed by both syngeneic and allogeneic HSCT (the latter 
Table 2

\begin{tabular}{|c|c|c|c|}
\hline \multirow[t]{2}{*}{ Rheumatological } & 500 & Neurological & 387 \\
\hline & & Multiple sclerosis & 368 \\
\hline Connective tissue disease & 308 & Myasthenia gravis & 3 \\
\hline Systemic sclerosis & 190 & Other/Unknown & 16 \\
\hline Systemic lupus erythematosus & 86 & & \\
\hline Polymyositis/dermatomyositis & 14 & Inflammatory bowel & 24 \\
\hline Sjögren & 3 & Crohn disease & 21 \\
\hline Other/Unknown & 15 & Ulcerative colitis & 3 \\
\hline Arthritis & 161 & Hematological & 67 \\
\hline Rheumatoid arthritis & 86 & ITP & 22 \\
\hline Juvenile arthritis & & Evans syndrome & 13 \\
\hline Systemic JIA & 41 & Autoimmune hemolytic anemia & 13 \\
\hline Other JIA & 18 & Pure red cell aplasia & 7 \\
\hline Polyarticular JIA & 10 & Pure white cell aplasia & 2 \\
\hline Psoriatic arthritis & 3 & Other & 10 \\
\hline \multirow[t]{2}{*}{ Other } & 3 & & \\
\hline & & Other/Unknown/Missing & 15 \\
\hline Vasculitis & 31 & & \\
\hline Wegener & 7 & & \\
\hline Behçet & 6 & & \\
\hline Takayasu & 2 & & \\
\hline Microscopic polyarteritis nodosa & 3 & & \\
\hline Classical polyarteritis nodosa & 1 & & \\
\hline Churg-Strauss syndrome & 2 & & \\
\hline Other/Unknown & 10 & & \\
\hline
\end{tabular}

Data from the EBMT/EULAR (European Group for Blood and Marrow Transplantation/European League Against Rheumatism) Registry, August 2008. ITP, immune thrombocytopenic purpura; JIA, juvenile idiopathic arthritis.

yielding a stable donor chimerism over 95\%) had a significant therapeutic effect compared with conditioning alone [15]. In this study, allogeneic HSCT was more effective than syngeneic HSCT in suppressing pathogenic autoantibodies.

In HLA-B27 transgenic rats, TBI followed by HSCT from nontransgenic mice led to a prompt and sustained remission of symptoms. In contrast, all rats who received a syngeneic transplant died from exacerbation of colitis [20].

In a recent study in lupus-prone New Zealand black/New Zealand white mice, it was shown that nonmyeloablative conditioning followed by infusion of highly purified allogeneic HSCs from a major histocompatibility complex-mismatched donor successfully induced durable mixed chimerism which was sufficient to treat established AD [12]. This treatment prolonged survival and reduced proteinuria, immune complex formation, and antinuclear antibodies (ANAs).

While the aforementioned preclinical studies have been instrumental in demonstrating basic principles of HSCT in experimental $A D$, the heterogeneity of results obtained in different transplant settings and disease models implies that extrapolation to the clinical setting in human $A D$ is difficult. Nevertheless, the data suggest that HSCT may be more effective (and probably less toxic) in patients with active progressive disease rather than end-stage advanced disease, a point that will be investigated in ongoing clinical trials.

\section{Clinical data}

Autologous hematopoietic stem cell transplantation

Autologous HSCT is the most widely used form of HSCT. In hemato-oncological conditions, it is a relatively safe procedure with a TRM typically below 3\%. Toxicities and transplant-related causes of death include sepsis, cytomegalovirus infection, and haemorrhage. The overall TRM for autologous HSCT in AD now is approximately $7 \%$, although it was as high as $23 \%$ in one of the first pilot studies [21]. In AD, diagnosis and extent of organ involvement, age, and comorbidity are patient-related determinants of toxicity and TRM (Figure 3). TRM and toxicity also depend on the conditioning regimen and whether or not $\mathrm{TBI}$ is performed [22]. With adaptation of eligibility criteria (for example, exclusion of patients with severe pulmonary hypertension) and modifica- 
Figure 1
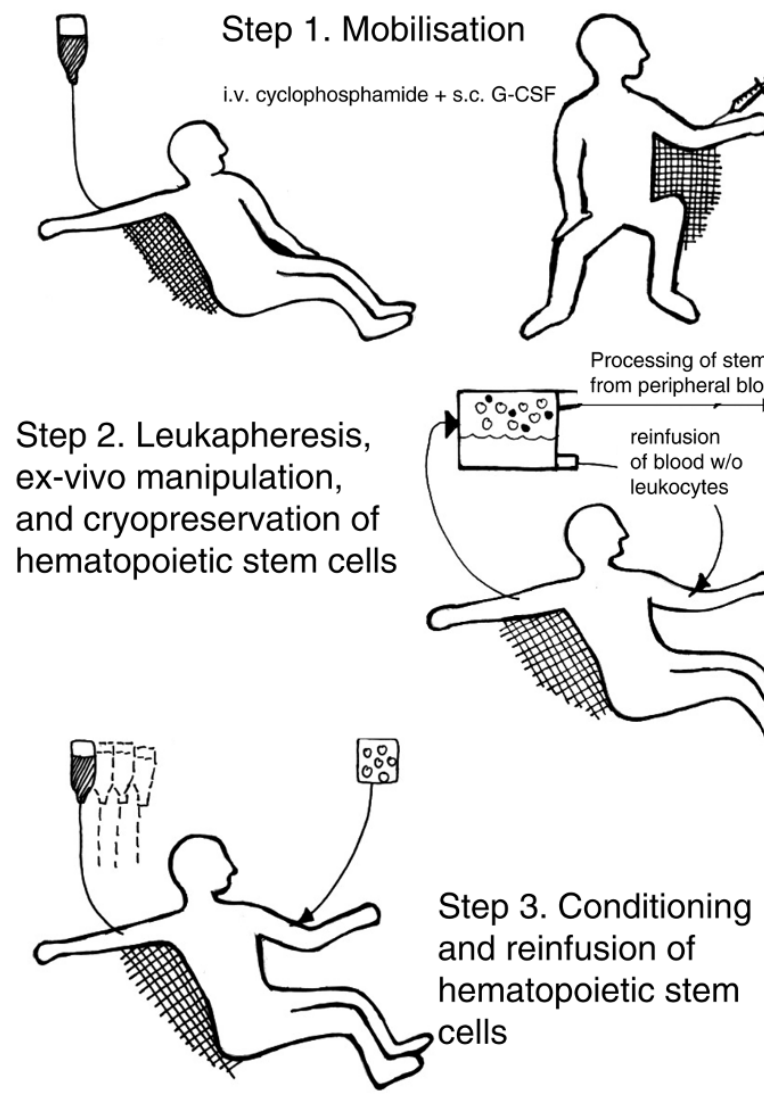

Hematopoietic stem cell transplantation (HSCT) is a complex multistep procedure involving mobilisation and harvesting of hematopoietic stem cells (HSCs) from blood or bone marrow, immunoablative therapy, followed by administration of HSCs. HSCs can be obtained from the patient (autologous), an identical twin (syngeneic), or an HLA-matched donor (allogeneic). The procedure of autologous HSCT starts with stem cell mobilisation from the peripheral blood, typically with granulocyte colony-stimulating factor (G-CSF) and cyclophosphamide. Stem cells are collected by plasmapheresis and selection for CD34 ${ }^{+}$ cells. Conditioning with $200 \mathrm{mg} / \mathrm{kg}$ cyclophosphamide with or without antithymocyte globuline (ATG) is then performed, followed by reinfusion of peripheral HSCs. Cyclophosphamide with or without ATG is considered as nonmyeloablative, whereas the combination of cyclophosphamide with total body irradiation or busulfan is considered as myeloablative conditioning. i.v., intravenous; s.c., subcutaneous.

tions of transplant regimens (for example, lung shielding with TBI), complications from HSCT can usually be managed in experienced hands, and TRM has dropped as a consequence. It was less than $1 \%$ for non-TBI nonmyeloablative, less than $2 \%$ for low-intensity myeloablative, and $13 \%$ for high-intensity myeloablative regimens [23]. Compared with TRM, efficacy seems less influenced by intensity and type of conditioning, although this may be confounded by the severity of underlying disease. In SLE patients, nonmyeloablative conditioning had an efficacy comparable to that of myeloablative conditioning with a markedly lower TRM of $2 \%$ versus $13 \%[1,24]$. A similar observation was made for SSc
Figure 2

Eradication of autoaggressive lymphocytes

Reduction of (auto)antibody production

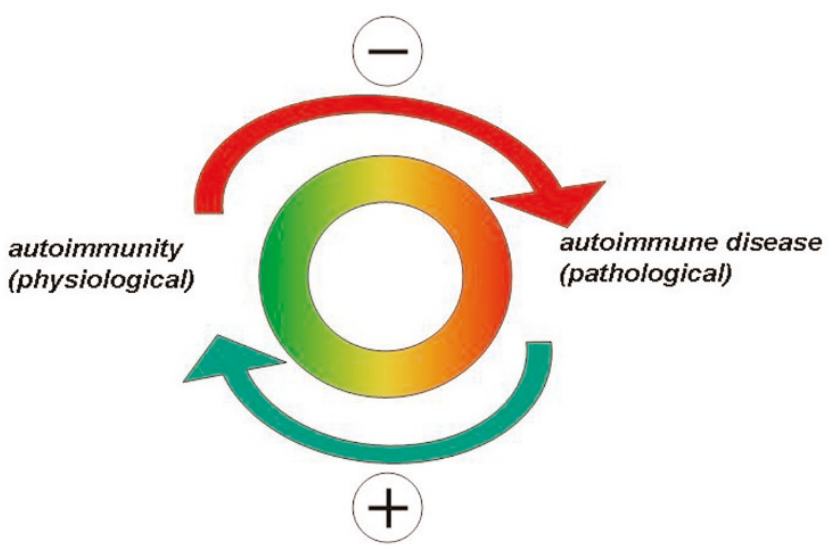

Restoration of thymic function, resulting in broadening of $T$ cell receptor repertoire and induction of regulatory $T$ cells

Restoration of cytokine imbalance

Induction of neoangiogenesis in skin

Resolution of skin fibrosis

Resetting of the immunological clock following hematopoietic stem cell transplantation.

where nonmyeloablative regimens had a TRM of less than $4 \%$ in contrast to $23 \%$ for myeloablative conditioning with $\mathrm{TBI}$, with similar efficacy $[21,25,26]$. Such comparisons, however, are not based on prospective controlled trials and must therefore be interpreted with caution.

Nonmyeloablative autologous HSCT in SLE patients resulted in a disease-free 5-year survival of 50\% and an overall 5-year survival of $84 \%$ with improvements of SLEDAI (Systemic Lupus Erythematosus Disease Activity Index) scores and ANA, anti-double-stranded DNA, and complement levels, as shown in a single-centre study [24]. A retrospective multicentre analysis of 53 patients of the EULAR/EBMT registry showed an improvement of SLEDAl scores in 66\%, but one third relapsed subsequently (after 3 to 40 months) [1]. Autologous HSCT also proved effective in antiphospholipid syndrome: 10 of 22 patients discontinued anticoagulation therapy, $78 \%$ of whom remained without further thrombotic events [27]. Interestingly, soft tissue calcifications resolved after autologous HSCT [28].

In patients with SSc, the 5-year event-free survival after HSCT in the North American and European studies was $64 \%$ $[21,26]$. Autologous HSCT resulted in a remarkable reversal of skin thickening, quality of life, and stabilisation of organ 
Figure 3
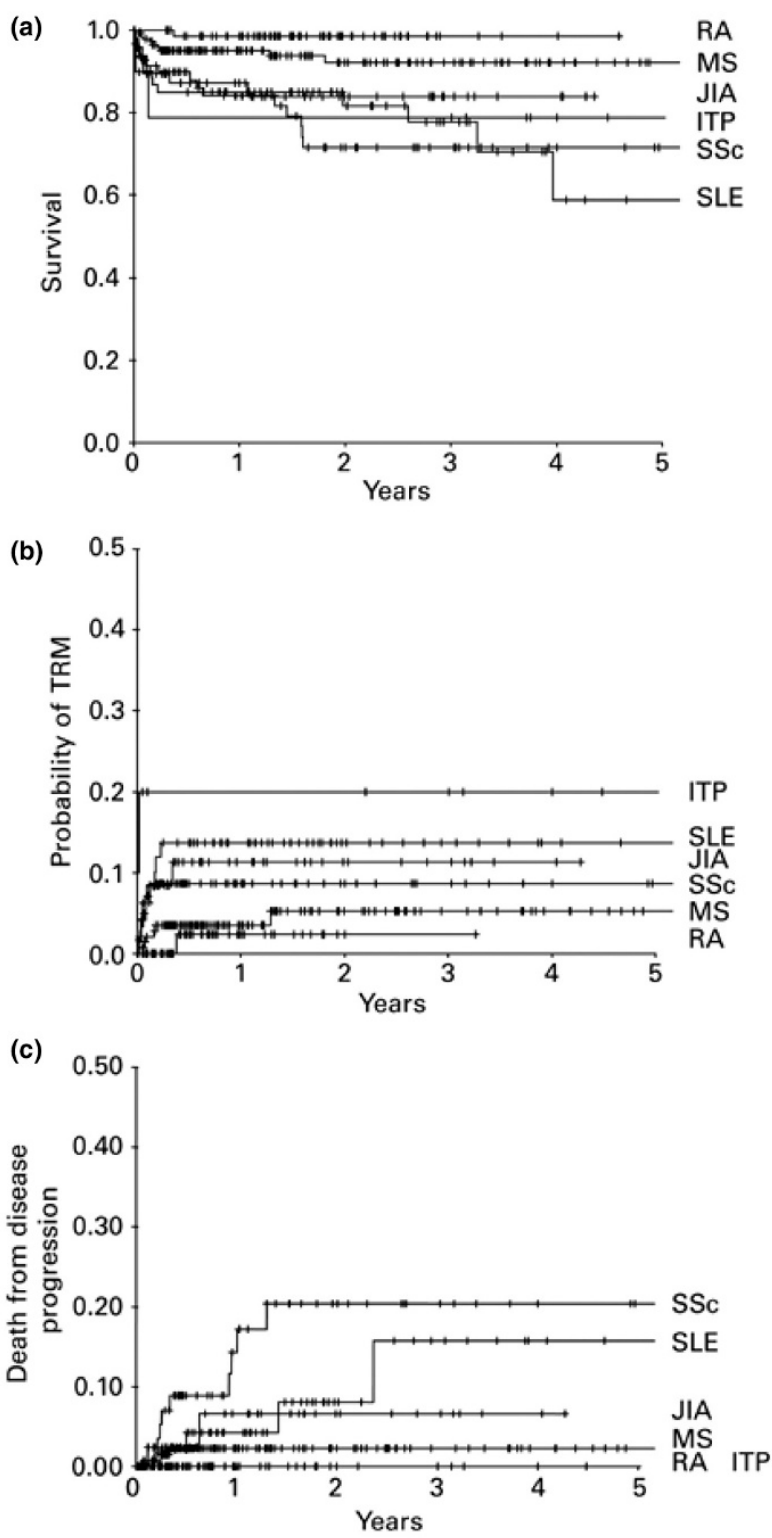

Outcome of patients with autologous hematopoietic stem cell transplantation for severe autoimmune disease. (a) Probability of survival $(n=414)$. The 3-year probabilities of survival were $99 \% \pm 3 \%$ in 70 rheumatoid arthritis (RA) patients, $92 \% \pm 5 \%$ in 150 multiple sclerosis (MS) patients, $84 \% \pm 11 \%$ in 51 juvenile idiopathic arthritis (JIA) patients, $79 \% \pm 27 \%$ in 10 immune thrombocytopenia (ITP) patients, $72 \% \pm 13 \%$ in 71 systemic sclerosis (SSc) patients, and $78 \% \pm 13 \%$ in 62 systemic lupus erythematosus (SLE) patients. $P=0.0004$ for a global log-rank test. (b) Probability of treatment-related mortality (TRM). The 3-year probabilities of TRM were $2 \% \pm 5 \%$ in RA patients, $5 \% \pm 5 \%$ in MS patients, $11 \% \pm 10 \%$ in JIA patients, $20 \% \pm 25 \%$ in ITP patients, $9 \% \pm 7 \%$ in SSc patients, and $14 \% \pm 9 \%$ in SLE patients. $P=0.24$ for a global log-rank test. (c) Probability of death from disease progression. The 3-year probabilities were $20 \% \pm 13 \%$ in SSc patients, $0 \%$ in RA patients, $7 \% \pm 9 \%$ in JIA patients, $16 \% \pm 17 \%$ in SLE patients, $2 \% \pm 3 \%$ in MS patients, and $0 \%$ in ITP patients. $P=0.005$ for a global log-rank test. Reprinted with permission from [22]. Copyright 2005, Nature Publishing Group. function $[25,26]$. A significant decrease in the modified Rodnan skin score was achieved in $73 \%$ of 26 patients after 1 year and in $94 \%$ after 5 years. Relapses of SSc occurred in a third of the cases after 2 to 4 years $[3,26]$. Stabilisation of heart, lung, and kidney function was seen after autologous HSCT. Persistent changes in capillary structure have been described recently after autologous HSCT in seven patients $[29,30]$. A comprehensive study on vascular markers in skin biopsies before and after transplant suggested that HSCT induces neoangiogenesis [31].

Three prospective studies are ongoing to investigate the safety and efficacy of nonmyeloablative conditioning followed by autologous HSCT compared with monthly intravenous pulse cyclophosphamide in SSc patients: the Autologous Stem Cell Transplantation International Scleroderma (ASTIS) trial in Europe and the American Scleroderma Stem Cell versus Immune Suppression Trial (ASSIST) and the Scleroderma: Cyclophosphamide or Transplantation Trial (SCOT) in North America. In the SCOT trial, a TBI-based myeloablative approach is used whereas ASTIS and ASSIST use a lymphodepleting regimen with ATG. At the time of this writing, 124 patients have been randomly assigned in the first of these trials (ASTIS trial). Long-term follow-up will be needed in all trials to evaluate durability of responses and late toxicities.

In RA, autologous HSCT was analysed in several studies. A registry analysis of 76 cases showed an American College of Rheumatology $50 \%$ improvement in $67 \%$ of patients and a significant reduction in the level of disability [32,33]. However, the relapse rate was high and disease-modifying antirheumatic drugs (DMARDs) had to be reintroduced in most of the patients. Interestingly, sensitivity to DMARDs seemed restored after HSCT. The availability of effective biologicals to treat severe RA has led to a reduced demand for intensive therapies such as (autologous) HSCT. Similar to RA, autologous HSCT showed a response rate of $68 \%$ in severe JIA. However, 5 of 20 responding patients relapsed, and a significant TRM including some cases of macrophage activation syndrome was reported [34]. Two case series showed positive effects of autologous HSCT in systemic vasculitis. Four patients were treated with nonmyeloablative stem cell transplantation (two with neurovascular Behçet disease, one with neurovascular Sjögren syndrome, and one with Wegener granulomatosis), and three remained in complete remission after 2 years [35]. One patient with Behçet disease did not improve. A further study reported an $86 \%$ response in 14 patients with different types of vasculitis. The median duration of response was 45 months. Two of the patients relapsed; no TRM in these patients was reported [36].

High-dose cyclophosphamide conditioning without stem cell rescue has been tested in SLE and scleroderma patients [37-39]. The rationale for that procedure is a rapid eradication of autoreactive effector cells while sparing stem cells because their high content of aldehyde dehydrogenase 
inactivates cyclophosphamide metabolic products. In SLE, 5 of 14 patients had a complete response, 6 had a partial response, and no TRM was reported. In 6 SSc patients, 1 patient died of TRM and 2 relapsed, whereas 3 had a sustained response after 12 to 24 months. These observations suggest that the key therapeutic effect from autologous HSCT is achieved by high-dose cyclophosphamide but do not exclude a role for HSCT as the long-term effects of this regimen are unknown. In addition, due to safety concerns, this variant protocol has not been adopted in other centres.

\section{Allogeneic hematopoietic stem cell transplantation}

In allogeneic HSCT, HSCs are collected from related (HLAmatched) siblings or matched unrelated donors. Different conditioning regimens are employed, usually involving two cytotoxic agents (for example, fludarabin + busulphan), and ATG with or without TBI. Post-transplant immunosuppression is given to prevent GVHD, typically with cyclosporin or methotrexate. Allogeneic HSCT is the only therapy that offers the prospect of a cure for AD, due to its ability to induce a graft-versus-autoimmunity effect, but its attendant risk of GVHD precludes its routine use in AD. Long-term remissions have been observed in several patients with $A D$ as well as in patients with concomitant hematologic malignancy who relapsed or did not respond to autologous HSCT [40]. In 23 patients with aplastic anemia and concomitant $A D$, the survival after allogeneic HSCT in complete remission of AD was $64 \%$ at 13 years; TRM was $21.7 \%$. In two patients with concomitant organ-specific autoimmunity (one with autoimmune thyroiditis and one with type 1 diabetes), AD did not resolve but favourable responses were seen in 21 patients suffering from RA, SLE, discoid lupus, eosinophilic fasciitis, and psoriasis. The studies suggest that allogeneic HSCT leads to a high relapse-free survival in patients with $A D$ and concomitant hematologic disease. Two SSc patients treated with allogeneic HSCT showed improvement of skin thickening and resolution of abnormalities on high-resolution computed tomography and/or bronchoalveolar lavage [41]. Both received myeloablative conditioning and developed full donor chimerism. One patient developed chronic GVHD necessitating immunosuppression and died after 18 months due to pseudomonas sepsis. In two other SSc patients, a chimerism of $10 \%$ to $15 \%$ after nonmyeloablative conditioning was associated with a sustained complete remission for over 3 years without GVHD [42,43]. In the only reported case of nonmyeloablative conditioning plus allogeneic HSCT in $\mathrm{RA}$, mixed chimerism resulted in marked amelioration of RA, without GVHD. The patient underwent HSCT from her HLAmatched sister and went into complete remission with 55\% donor T (CD3) cells and 70\% donor myeloid (CD33) cells [44]. Remissions lasting 2 to 13 years have been reported in three RA patients who received myeloablative conditioning and allogeneic HSCT for concomitant hematologic malignant disease [45]. Remissions lasting several years have also been seen in vasculitis due to Behçet's and Wegener's disease $[36,46]$.
In a recent retrospective analysis of the European EBMT (ProMISe) database, the outcome of 38 allogeneic HSCTs in 35 patients was analysed (T. Daikeler, T. Hügle, D. Farge, M. Andolina, F. Gualandi, H. Baldomero, C. Bocelli-Tyndall, M. Brune, J.H. Dalle, G. Ehninger, B.E. Gibson, B. Linder, B. Lioure, A.M. Marmont, S. Matthes-Martin, D. Nachbaur, P. Schuetz, A. Tyndall, J.M. van Laar, P. Veys, R. Saccardi, A. Gratwohl, submitted for publication). In that study, $55 \%$ of the patients showed a complete clinical response of their refractory disease and a total of $79 \%$ of patients responded at least partially. TRM at 2 years was $22.1 \%$, in line with results in conventional hematologic diseases [40]. The probability of survival at 2 years was $70 \%$. TBI-containing conditioning was associated with a higher mortality and responses tended to be better when conditioning included cyclophosphamide.

Safety of allogeneic HSCT has improved by employing reduced-intensity regimens, graft manipulation like T-cell depletion, and new methods to prevent GVHD such as administration of mesenchymal stem cells or T-regulatory cells [47]. In a recent prospective clinical trial, 56 patients with severe acute GVHD were treated with mesenchymal stem cells obtained from HLA-identical siblings or haploidentical or HLA-mismatched donors: 30 of 56 patients had a complete response, and 9 had a partial response. No side effects were reported. Interestingly, patients with a complete response had lower TRM compared with those with partial or no response and they had a higher overall survival 2 years after HSCT [48]. Conditioning with alemtuzumab, a monoclonal anti-CD52 antibody targeting B cells, T cells, and DCs, is increasingly used for nonmyeloablative regimens. In another recent study, GVHD was significantly reduced in patients with aplastic anemia albeit at the expense of a higher rate of cytomegalovirus reactivation [49].

\section{Mechanisms of action of hematopoietic stem cell transplantation in autoimmune disease Autologous hematopoietic stem cell transplantation} In autologous HSCT, conditioning with high-dose cyclophosphamide, ATG, and/or TBI deletes the majority of autoreactive effector cells of the host. Both adaptive and innate immune cells, including B and T lymphocytes, monocytes, NK cells, and DCs, are affected. This intensive immunosuppressive effect is considered to be the key effect of HSCT on AD, at least in the short term. The infusion of autologous HSCs serves to shorten aplasia but is probably not essential for the direct anti-autoimmune effect [38]. In animal models, better response rates are seen in early inflammatory disease than in chronic longstanding AD [11]. The latter may be due to a more important role of the stromal cell compartment, difficulties in disentangling disease activity from damage, or reduced sensitivity of the immune system to tolerance induction in longstanding disease [50].

Survival of autoreactive host lymphocytes with persistence of autoantibody titres after autologous HSCT has been 
described after both myeloablative and nonmyeloablative conditioning. Such cells may contribute to relapses. This implies that, in those patients without relapses, there must be factors that either inhibit proliferation of autoreactive clones or render the host anergic. These may include nonspecific effects of immunoablative therapy, such as post-transplant lymphopenia and reduced levels of pathogenic autoantibodies, and more specific effects, such as the induction of regulatory $T$ cells. In the proteoglycan-induced arthritis mouse model, the initial improvement after autologous HSCT corresponded to an increase in $\mathrm{CD} 4{ }^{+} \mathrm{CD} 25^{+}$cells [51]. Initially, these T-regulatory cells did not express FoxP3. Subsequent FoxP3 expression, however, was associated with a further stabilisation of AD. Similar results have been found in patients with juvenile chronic arthritis [52]. After autologous HSCT, autoreactive $T$ cells changed from a proinflammatory phenotype (mRNA interferon-gamma, T-bet high) before HSCT toward a tolerant phenotype (IL-10 and GATA-3 high). T-regulatory cells markedly increased after autologous HSCT. In the first period, they reconstitute through homeostatic clonal expansion; after several months, a thymic-dependent naïve $\mathrm{CD} 4{ }^{+} \mathrm{CD} 25^{+} \mathrm{T}$-regulatory cell regeneration is seen [52]. Interestingly, most of the relapses after autologous HSCT occurred within the first 9 months after HSCT, before the thymus-dependent recovery of naïve T-regulatory cells. Therefore, it is postulated that a well-functioning thymus is needed to generate a functionally active $\mathrm{CD} 4{ }^{+} \mathrm{CD} 25^{+}$ population. Evidence for thymic reactivation after autologous HSCT has been obtained from studies showing increases in $\mathrm{T}$-cell receptor excision circles and $\mathrm{CD} 31^{+} \mathrm{T}$ cells and normalisation of new T-cell receptor repertoires $[53,54]$.

\section{Allogeneic hematopoietic stem cell transplantation}

The interaction of two different immune systems in one individual makes the pathogenetic mechanisms more complex in the allogeneic situation. When first performed in patients with $A D$, myeloablative chemo(radio)therapy was performed in conjunction with allogeneic HSCT, in analogy to hematological diseases, in order to eradicate the host immune system [41]. However, as shown in both animal models and several patients, nonmyelablative conditioning equally yielded stable mixed chimerism, resulted in less GVHD, and had the same efficacy in $A D$ as myeloablative conditioning $[12,43]$.

After allogeneic HSCT, immune reconstitution depends on different factors such as stem cell source (peripheral blood versus bone marrow $[B M]$, syngeneic versus allogeneic, and HLA-matched versus -mismatched), graft manipulation (mainly T-cell depletion), and age of the patient. Recovery of innate immunity (NK cells, monocytes, and granulocytes) occurs rapidly following transplantation whereas that of adaptive immunity is delayed and mostly incomplete [55]. Especially after T-cell depletion of the donor graft, persistent low $\mathrm{CD}^{+}{ }^{+} \mathrm{T}$-cell numbers are observed $[56,57]$. Reconstitution of $\mathrm{CD}^{+}{ }^{+} \mathrm{T}$ cells is more dependent on thymic function than CD8 cells. The grade of immunosuppression also depends on the type of graft source: unmanipulated peripheral blood stem cell (PBSC) grafts contain more T cells than BM grafts with a preserved CD4/CD8 ratio and a less activated immunophenotype [58]. Recovery is significantly faster for CD4 cells, circulating monocytes, and NK cells after HSCT from peripheral blood versus BM [59]. Cytokine profiles of PBSC-harvested T cells are polarised toward type II responses and these $T$ cells exhibit a reduced ability to respond to allo- or autoantigens [58]. BM, in contrast, contains more T-regulatory cells and mesenchymal stem cells than PBSCs. Both of them possess strong immunosuppressive effects, which may explain why more infections are observed after BM transplantation compared with PBSCs [60].

The role of T-regulatory cells after allogeneic HSCT has been analysed in chronic GVHD. The deficiency of T-regulatory cells due to consumption during acute GVHD probably contributes to chronic GVHD [61]. On the other hand, in the absence of GVHD, an increase of the anti-inflammatory IL-10 is described which may promote the formation of T-regulatory cells. Apart from the increase of IL-10 serum levels, reduced levels of interferon, tumour necrosis factor-alpha, and IL-17 from stimulated $T$ cells of mice with chronic inflammatory arthritis were described after allogeneic HSCT [17]. More specifically, autoantigen-presenting cells are postulated to be attacked and eliminated by the allograft [62]. Donor precursor T or NK cells are attracted by host antigen-presenting cells, presenting so-called host minor histocompability antigens. DCs, specialised in presenting antigens to donor effector cells, are mainly involved in this setting and probably also in autoantigen (cross)presentation in AD. In most tissues, recipient DCs are replaced after transplantation due to rapid turnover of BM-derived precursors [63]. However, in a number of sites, notably the skin, recipient DCs may persist and even self-renew for many months after transplantation.

In collagen-induced arthritis, donor NK cells specifically eradicated autoantibody-producing plasma cells whereas other plasma cells remained unaffected [64]. In lupus-prone mice, a significant decrease of ANAs was observed after allogeneic and, to a lesser extent, after syngeneic HSCT [12]. The decrease of pathogenic autoantibodies and switch of subclass toward IgG1 may also be relevant [17]. The total immunoglobulin levels after allogeneic HSCT decrease early after transplantation. Meanwhile, there are several reports of resolution of fibrosis after allogeneic HSCT. In this context, two patients who received allogeneic HSCT for scleroderma showed a resolution of collagenous deposits in the dermis [41]. So far, however, the mechanism of this remains unclear.

\section{Summary and outlook}

Immunoablative therapy followed by HSCT has evolved from an experimental treatment to a salvage therapy for patients with severe $A D$ not responding to proven conventional therapy and/or biologicals. While safety of transplant procedures in $A D$ in general has markedly improved through 


\section{The Scientific Basis of Rheumatology: years A Decade of Progress}

This article is part of a special collection of reviews, The Scientific Basis of Rheumatology: A Decade of Progress, published to mark Arthritis Research \& Therapy's 10th anniversary.

Other articles in this series can be found at: http://arthritis-research.com/sbr

better patient selection and modifications of transplant protocols, patients with organ involvement from connective tissue disease in particular are at risk of serious adverse events and TRM. On the other hand, HSCT has the potential to induce a sustained remission and this has been consistently observed in SSc and SLE. Prospective randomised controlled trials are in progress to evaluate risks and benefits of HSCT versus conventional therapies and investigate predictive factors of responsiveness. Both autologous and allogeneic HSCT induce profound alterations of the immune system, including restoratorion of regulatory mechanisms, but their relationship with clinical effects merits further studies. Immunoablative therapy and HSCT (autologous and allogeneic) in $A D$ is a highly complex procedure that should be done only in specialised centres in the context of approved study protocols in accordance with established guidelines [65].

\section{Competing interests}

The authors declare that they have no competing interests.

\section{Acknowledgements}

The authors would like to thank Riccardo Saccardi, chair of the EBMT/EULAR Working Party Autoimmune Diseases, for providing permission to incorporate registry data from the Autoimmune Disease Database.

\section{References}

1. Jayne D, Passweg J, Marmont A, Farge D, Zhao X, Arnold R, Hiepe F, Lisukov I, Musso M, Ou-Yang J, Marsh J, Wulffraat N, Besalduch J, Bingham SJ, Emery P, Brune M, Fassas A, Faulkner L, Ferster A, Fiehn C, Fouillard L, Geromin A, Greinix H, Rabusin M, Saccardi R, Schneider P, Zintl F, Gratwohl A, Tyndall A; European Group for Blood and Marrow Transplantation, et al.: Autologous stem cell transplantation for systemic lupus erythematosus. Lupus 2004, 13:168-176.

2. Saccardi R, Kozak T, Bocelli-Tyndall C, Fassas A, Kazis A, Havrdova E, Carreras E, Saiz A, Löwenberg B, te Boekhorst PA, Gualandio $F$, Openshaw H, Longo G, Pagliai F, Massacesi L, Deconink E, Ouyang J, Nagore FJ, Besalduch J, Lisukov IA, Bonini A, Merelli E, Slavino S, Gratwohl A, Passweg J, Tyndall A, Steck $\mathrm{AJ}$, Andolina M, Capobianco M, Martin JL, et al.: Autologous stem cell transplantation for progressive multiple sclerosis: update of the European Group for Blood and Marrow Transplantation autoimmune diseases working party database. Mult Scler 2006, 12:814-823.
3. Farge D, Passweg J, van Laar JM, Marjanovic Z, Besenthal C, Finke J, Peter HH, Breedveld FC, Fibbe WE, Black C, Denton C, Koetter I, Locatelli F, Martini A, Schattenberg AV, van den Hoogen F, van de Putte L, Lanza F, Arnold R, Bacon PA, Bingham S, Ciceri F, Didier B, Diez-Martin JL, Emery P, Feremans W, Hertenstein $\mathrm{B}$, Hiepe $\mathrm{F}$, Luosujärvi $\mathrm{R}$, Leon Lara $\mathrm{A}$, et al.: Autologous stem cell transplantation in the treatment of systemic sclerosis: report from the EBMT/EULAR Registry. Ann Rheum Dis 2004, 63:974-981.

4. Tyndall A, Saccardi R: Haematopoietic stem cell transplantation in the treatment of severe autoimmune disease: results from phase I/II studies, prospective randomized trials and future directions. Clin Exp Immunol 2005, 141:1-9.

5. Nelson JL, Torrez R, Louie FM, Choe OS, Storb R, Sullivan KM: Pre-existing autoimmune disease in patients with long-term survival after allogeneic bone marrow transplantation. J Rheumatol 1997, 48:23-29.

6. van Bekkum DW: Stem cell transplantation in experimental models of autoimmune disease. J Clin Immunol 2000, 20:1016.

7. Morton Jl, Siegel BV: Transplantation of Autoimmune Potential. I. Development of Antinuclear Antibodies in H-2 Histocompatible Recipients of Bone Marrow from New Zealand Black Mice. Proc Natl Acad Sci U S A 1974, 71:2162-2165.

8. Ikehara S, Kawamura M, Takao F, Inaba M, Yasumizu R, Than S, Hisha H, Sugiura K, Koide Y, Yoshida TO, Ida T, Imura H, Good RA: Organ-specific and systemic autoimmune diseases originate from defects in hematopoietic stem cells. Proc Natl Acad Sci U S A 1990, 87:8341-8344.

9. van Laar JM: Immune ablation and stem-cell therapy in autoimmune disease. Immunological reconstitution after highdose immunosuppression and haematopoietic stem-cell transplantation. Arthritis Res 2000, 2:270-275.

10. van Gelder M, van Bekkum DW: Effective treatment of relapsing experimental autoimmune encephalomyelitis with pseudoautologous bone marrow transplantation. Bone Marrow Transplant 1996, 18:1029-1034.

11. Van Wijmeersch $B$, Sprangers $B$, Rutgeerts $O$, Lenaerts $C$, Landuyt W, Waer M, Billiau AD, Dubois B: Allogeneic bone marrow transplantation in models of experimental autoimmune encephalomyelitis: evidence for a graft-versus-autoimmunity effect. Biol Blood Marrow Transplant 2007, 13:627-637.

12. Smith-Berdan S, Gille D, Weissman IL, Christensen JL: Reversal of autoimmune disease in lupus-prone New Zealand black/New Zealand white mice by nonmyeloablative transplantation of purified allogeneic hematopoietic stem cells. Blood 2007, 15:110.

13. Burt RK, Padilla J, Begolka WS, Canto MC, Miller SD: Effect of disease stage on clinical outcome after syngeneic bone marrow transplantation for relapsing experimental autoimmune encephalomyelitis. Blood 1998, 91:2609-2616.

14. Herrmann MM, Gaertner S, Stadelmann C, van den Brandt J, Böscke R, Budach W, Reichardt HM, Weissert R: Tolerance induction by bone marrow transplantation in a multiple sclerosis model. Blood 2005, 106:1875-1883.

15. Flierman R, Witteveen HJ, van der Voort El, Huizinga TW, de Vries RR, Fibbe WE, Toes RE, van Laar JM: Control of systemic B cell-mediated autoimmune disease by nonmyeloablative conditioning and major histocompatibility complex-mismatched allogeneic bone marrow transplantation. Blood 2005, 105: 2991-2994.

16. Cho SG, Min SY, Park MJ, Lee KW, Cho YG, Cho ML, Chang HS, Park SH, Lee JW, Min WS, Kim CC, Kim HY: Immunoregulatory effects of allogeneic mixed chimerism induced by nonmyeloablative bone marrow transplantation on chronic inflammatory arthritis and autoimmunity in interleukin-1 receptor antagonist-deficient mice. Arthritis Rheum 2006, 54: 1878-1887.

17. Wekerle T, Kurtz J, Ito H, Ronquillo JV, Dong V, Zhao G, Shaffer J, Sayegh MH, Sykes M: Allogeneic bone marrow transplantation with co-stimulatory blockade induces macrochimerism and tolerance without cytoreductive host treatment. Nat Med 2000, 6:464-469.

18. Czechowicz A, Kraft D, Weissman IL, Bhattacharya D: Efficient transplantation via antibody-based clearance of hematopoietic stem cell niches. Science 2007, 318:1296-1299.

19. Ogawa M, Matsuzaki Y, Nishikawa S, Hayashi S, Kunisada T, 
Sudo T, Kina T, Nakauchi H, Nishikawa S: Expression and function of c-kit in hemopoietic progenitor cells. J Exp Med 1991, 174:63-71.

20. Breban M, Hammer RE, Richardson JA, Taurog JD: Transfer of the inflammatory disease of HLA-B27 transgenic rats by bone marrow engraftment. J Exp Med 1993, 178:1607-1616.

21. Nash RA, McSweeney PA, Crofford LJ, Abidi M, Chen CS, Godwin JD, Gooley TA, Holmberg L, Henstorf G, LeMaistre CF, Mayes MD, McDonagh KT, McLaughlin B, Molitor JA, Nelson JL, Shulman H, Storb R, Viganego F, Wener MH, Seibold JR, Sullivan KM, Furst DE: High-dose immunosuppressive therapy and autologous hematopoietic cell transplantation for severe systemic sclerosis: long-term follow-up of the US multicenter pilot study. Blood 2007, 110:1388-1396.

22. Gratwohl A, Passweg J, Bocelli-Tyndall C, Fassas A, van Laar JM, Farge D, Andolina M, Arnold R, Carreras E, Finke J, Kötter I, Kozak T, Lisukov I, Löwenberg B, Marmont A, Moore J, Saccardi R, Snowden JA, van den Hoogen F, Wulffraat NM, Zhao XW, Tyndall A; Autoimmune Diseases Working Party of the European Group for Blood and Marrow Transplantation (EBMT): Autologous hematopoietic stem cell transplantation for autoimmune diseases. Bone Marrow Transplant 2005, 35:869-879.

23. Burt RK, Loh Y, Pearce W, Beohar N, Barr WG, Craig R, Wen Y, Rapp JA, Kessler J: Clinical applications of blood-derived and marrow-derived stem cells for nonmalignant diseases. JAMA 2008, 299:925-936.

24. Burt RK, Traynor A, Statkute L, Barr WG, Rosa R, Schroeder J, Verda L, Krosnjar N, Quigley K, Yaung K, Villa Bs M, Takahashi M, Jovanovic B, Oyama Y: Nonmyeloablative hematopoietic stem cell transplantation for systemic lupus erythematosus. JAMA 2006, 295:527-535.

25. Oyama Y, Barr WG, Statkute L, Corbridge T, Gonda EA, Jovanovic B, Testori A, Burt RK: Autologous non-myeloablative hematopoietic stem cell transplantation in patients with systemic sclerosis. Bone Marrow Transplant 2007, 40:549-555.

26. Vonk MC, Marjanovic Z, van den Hoogen FH, Zohar S, Schattenberg AV, Fibbe WE, Larghero J, Gluckman E, Preijers FW, van Dijk AP, Bax JJ, Roblot P, van Riel PL, van Laar JM, Farge D: Long-term follow-up results after autologous haematopoietic stem cell transplantation for severe systemic sclerosis. Ann Rheum Dis 2008, 67:98-104.

27. Statkute L, Traynor A, Oyama Y, Yaung K, Verda L, Krosnjar N, Burt RK: Antiphospholipid syndrome in patients with systemic lupus erythematosus treated by autologous hematopoietic stem cell transplantation. Blood 2005, 106:2700-2709.

28. Mandelbrot DA, Santos PW, Burt RK, Oyama Y, Block GA, Ahya SN, Rosa RM, Traynor AE: Resolution of SLE-related softtissue calcification following haematopoietic stem cell transplantation. Nephrol Dial Transplant 2008, 23:2679-2684.

29. Aschwanden M, Daikeler T, Jaeger KA, Thalhammer C, Gratwohl A, Matucci-Cerinic M, Tyndall A: Rapid improvement of nailfold capillaroscopy after intense immunosuppression for systemic sclerosis and mixed connective tissue disease. Ann Rheum Dis 2008, 67:1057-1059.

30. Miniati I, Guiducci S, Conforti ML, Rogai V, Fiori G, Cinelli M, Saccardi R, Guidi S, Bosi A, Tyndall A, Matucci Cerinic M: Autologous stem cell transplantation improves microcirculation in systemic sclerosis. Ann Rheum Dis 2008, May 26. [Epub ahead of print].

31. Fleming JN, Nash RA, McLeod DO, Fiorentino DF, Shulman HM, Connolly MK, Molitor JA, Henstorf G, Lafyatis R, Pritchard DK, Adams LD, Furst DE, Schwartz SM: Capillary regeneration in scleroderma: stem cell therapy reverses phenotype? PLOS ONE 2008, 16:e1452.

32. Snowden JA, Passweg J, Moore JJ, Milliken S, Cannell P, Van Laar J, Verburg R, Szer J, Taylor K, Joske D, Rule S, Bingham SJ, Emery P, Burt RK, Lowenthal RM, Durez P, McKendry RJ, Pavletic SZ, Espigado I, Jantunen E, Kashyap A, Rabusin M, Brooks P, Bredeson $\mathrm{C}$, Tyndall A: Autologous hemopoietic stem cell transplantation in severe rheumatoid arthritis: a report from the EBMT and ABMTR. J Rheumatol 2004, 31:482-488.

33. Verburg RJ, Kruize AA, van den Hoogen FH, Fibbe WE, Petersen EJ, Preijers F, Sont JK, Barge RM, Bijlsma JW, van de Putte LB, Breedveld FC, van Laar JM: High-dose chemotherapy and autologous hematopoietic stem cell transplantation in patients with rheumatoid arthritis: results of an open study to assess feasibility, safety, and efficacy. Arthritis Rheum 2001,
44:754-760.

34. Brinkman DM, de Kleer IM, ten Cate R, van Rossum MA, Bekkering WP, Fasth A, van Tol MJ, Kuis W, Wulffraat NM, Vossen JM: Autologous stem cell transplantation in children with severe progressive systemic or polyarticular juvenile idiopathic arthritis: long-term follow-up of a prospective clinical trial. Arthritis Rheum 2007, 56:2410-2421.

35. Statkute L, Oyama $Y$, Barr WG, Sufit R, Ho S, Verda L, Loh $Y$, Yaung K, Quigley K, Burt RK: Autologous non-myeloablative hematopoietic stem cell transplantation for refractory systemic vasculitis. Ann Rheum Dis 2008, 67:991-997.

36. Daikeler T, Kötter I, Bocelli Tyndall C, Apperley J, Attarbaschi A, Guardiola P, Gratwohl A, Jantunen E, Marmont A, Porretto $F$, Musso M, Maurer B, Rinaldi N, Saccardi R, Tyndall A; EBMT Autoimmune Diseases Working Party: Haematopoietic stem cell transplantation for vasculitis including Behcet's disease and polychondritis: a retrospective analysis of patients recorded in the European Bone Marrow Transplantation and European League Against Rheumatism databases and a review of the literature. Ann Rheum Dis 2007, 66:202-207.

37. Petri M, Jones RJ, Brodsky RA: High-dose cyclophosphamide without stem cell transplantation in systemic lupus erythematosus. Arthritis Rheum 2003, 48:166-173.

38. Tehlirian CV, Hummers LK, White B, Brodsky RA, Wigley FM: High-dose cyclophosphamide without stem cell rescue in scleroderma. Ann Rheum Dis 2008, 67:775-781.

39. Brodsky RA, Sensenbrenner LL, Jones RJ: Complete remission in severe aplastic anemia after high-dose cyclophosphamide without bone marrow transplantation. Blood 1996, 87:491494.

40. Hinterberger W, Hinterberger-Fischer M, Marmont A: Clinically demonstrable anti-autoimmunity mediated by allogeneic immune cells favorably affects outcome after stem cell transplantation in human autoimmune diseases. Bone Marrow Transplant 2002, 30:753-759.

41. Nash RA, McSweeney PA, Nelson JL, Wener M, Georges GE, Langston AA, Shulman H, Sullivan KM, Lee J, Henstorf G, Storb $\mathrm{R}$, Furst DE: Allogeneic marrow transplantation in patients with severe systemic sclerosis: resolution of dermal fibrosis. Arthritis Rheum 2006, 54:1982-1986.

42. Khorshid O, Hosing C, Bibawi S, Ueno N, Reveille J, Mayes MD, Champlin RE: Nonmyeloablative stem cell transplant in a patient with advanced systemic sclerosis and systemic lupus erythematosus. J Rheumato/ 2004, 31:2513-2516.

43. Loh Y, Oyama Y, Statkute L, Verda L, Quigley K, Yaung K, Barr W, Jovanovic B, Burt RK: Non-myeloablative allogeneic hematopoietic stem cell transplantation for severe systemic sclerosis: graft-versus-autoimmunity without graft-versushost disease? Bone Marrow Transplant 2007, 39:435-437.

44. Burt RK, Oyama Y, Verda L, Quigley K, Brush M, Yaung K, Statkute L, Traynor A, Barr WG: Induction of remission of severe and refractory rheumatoid arthritis by allogeneic mixed chimerism. Arthritis Rheum 2004, 50:2466-2470.

45. Snowden JA, Kearney P, Kearney A, Cooley HM, Grigg A, Jacobs P, Bergman J, Brooks PM, Biggs JC: Long-term outcome of autoimmune disease following allogeneic bone marrow transplantation. Arthritis Rheum 1998, 41:453-459.

46. Marmont AM, Gualandi F, Piaggio G, Podestà M, Teresa van Lint M, Bacigalupo A, Nobili F: Allogeneic bone marrow transplantation (BMT) for refractory Behçet's disease with severe CNS involvement. Bone Marrow Transplant 2006, 37:1061-1063.

47. Hoffmann $\mathrm{P}$, Edinger $\mathrm{M}: \mathrm{CD}^{+}{ }^{+} \mathrm{CD} 25^{+}$regulatory $\mathrm{T}$ cells and graft-versus-host disease. Semin Hematol 2006, 43:62-69.

48. Le Blanc K, Frassoni F, Ball L, Locatelli F, Roelofs H, Lewis I, Lanino E, Sundberg B, Bernardo ME, Remberger M, Dini G, Egeler RM, Bacigalupo A, Fibbe W, Ringdén O; Developmental Committee of the European Group for Blood and Marrow Transplantation: Mesenchymal stem cells for treatment of steroidresistant, severe, acute graft-versus-host disease: a phase II study. Lancet 2008, 10:1579-1586.

49. Siegal D, Xu W, Sutherland R, Kamel-Reid S, Kuruvilla J, Lipton $\mathrm{JH}$, Minden M, Messner H, Gupta V: Graft-versus-host disease following marrow transplantation for aplastic anemia: different impact of two GVHD prevention strategies. Bone Marrow Transplant 2008, 42:51-56.

50. Burnet FM: A modification of Jerne's theory of antibody production using the concept of clonal selection. CA Cancer $J$ 
Clin 1976, 26:119-121.

51. Roord STA, de Jager W, Boon L, Wulffraat N, Martens A, Prakken $B$, van Wijk F: Autologous bone marrow transplantation in autoimmune arthritis restores immune homeostasis through $\mathrm{CD}^{+}{ }^{+} \mathrm{CD} 25^{+}$Foxp $^{+}$regulatory T cells. Blood 2008, 111:52335241.

52. de Kleer I, Vastert B, Klein M, Teklenburg G, Arkesteijn G, Yung GP, Albani S, Kuis W, Wulffraat N, Prakken B: Autologous stem cell transplantation for autoimmunity induces immunologic self-tolerance by reprogramming autoreactive $T$ cells and restoring the $\mathrm{CD} 4{ }^{+} \mathrm{CD} 25^{+}$immune regulatory network. Blood 2006, 107:1696-1702.

53. Muraro PA, Douek DC, Packer A, Chung K, Guenaga FJ, Cassiani-Ingoni R, Campbell C, Memon S, Nagle JW, Hakim FT, Gress RE, McFarland HF, Burt RK, Martin R: Thymic output generates a new and diverse TCR repertoire after autologous stem cell transplantation in multiple sclerosis patients. $J$ Exp Med 2005, 201:805-816.

54. Thiel A, Alexander T, Schmidt CA, Przybylski GK, Kimmig S, Kohler S, Radtke H, Gromnica-lhle E, Massenkeil G, Radbruch A, Arnold R, Hiepe F: Direct assessment of thymic reactivation after autologous stem cell transplantation. Acta Haematol 2008, 119:22-27.

55. Peggs KS: Reconstitution of adaptive and innate immunity following allogeneic hematopoietic stem cell transplantation in humans. Cytotherapy 2006, 8:427-436.

56. Hakim FT, Cepeda R, Kaimei S, Mackall CL, McAtee N, Zujewski J, Cowan K, Gress RE: Constraints on CD4 recovery postchemotherapy in adults: thymic insufficiency and apoptotic decline of expanded peripheral CD4 cells. Blood 1997, 90: 3789-3798.

57. Mackall CL, Fleisher TA, Brown MR, Andrich MP, Chen CC, Feuerstein IM, Magrath IT, Wexler LH, Dimitrov DS, Gress RE: Distinctions between $\mathrm{CD}^{+}$and $\mathrm{CD}^{+}{ }^{+} \mathrm{T}$-cell regenerative pathways result in prolonged $\mathrm{T}$-cell subset imbalance after intensive chemotherapy. Blood 1997, 89:3700-3707.

58. Tayebi H, Kuttler F, Saas P, Lienard A, Petracca B, Lapierre V, Ferrand C, Fest T, Cahn 'J, Blaise D, Kuentz M, Hervé P, Tiberghien $\mathrm{P}$, Robinet E: Effect of granulocyte colony-stimulating factor mobilization on phenotypical and functional properties of immune cells. Exp Hematol 2001, 29:458-470.

59. Talmadge JE, Reed E, Ino K, Kessinger A, Kuszynski C, Heimann D, Varney M, Jackson J, Vose JM, Bierman PJ: Rapid immunologic reconstitution following transplantation with mobilized peripheral blood stem cells as compared to bone marrow. Bone Marrow Transplant 1997, 19:161-172.

60. Storek J, Dawson MA, Storer B, Stevens-Ayers T, Maloney DG, Marr KA, Witherspoon RP, Bensinger W, Flowers ME, Martin P, Storb R, Appelbaum FR, Boeckh M: Immune reconstitution after allogeneic marrow transplantation compared with blood stem cell transplantation. Blood 2001, 97:3380-3389.

61. Chen X, Vodanovic-Jankovic S, Johnson B, Keller M, Komorowski $\mathrm{R}$, Drobyski WR: Absence of regulatory T-cell control of TH1 and TH17 cells is responsible for the autoimmune-mediated pathology in chronic graft-versus-host disease. Blood 2007, 110:3804-3813.

62. Ruggeri L, Capanni M, Urbani E, Perruccio K, Shlomchik WD, Tosti A, Posati S, Rogaia D, Frassoni F, Aversa F, Martelli MF, Velardi A: Effectiveness of donor natural killer cell alloreactivity in mismatched hematopoietic transplants. Science 2002, 295:2097-2100.

63. Kamath AT, Henri S, Battye F, Tough DF, Shortman K: Developmental kinetics and lifespan of dendritic cells in mouse lymphoid organs. Blood 2002, 100:1734-1741.

64. Flierman R, Westerhuis G, Hameetman M, van Duivenvoorde LM, van Hall T, van Laar JM, Fibbe WE, Toes RE: Targeting host Bcell immune responses by persistent donor NK-cell alloreactivity following nonmyeloablative allogeneic stem cell transplantation. Blood 2007, 109:5524-5525.

65. Tyndall $A$, Gratwohl A: Blood and marrow stem cell transplants in autoimmune disease. A consensus report written on behalf of the European League Against Rheumatism (EULAR) and the European Group for Blood and Marrow Transplantation (EBMT). Br J Rheum 1997, 36:390-392. 